\title{
NIEDOŚWIADCZENIE, NIEDOŁĘSTWO LUB PRZYMUSOWE POŁOŻENIE WSPÓLNIKA SPÓŁKI CYWILNEJ. ROZWAŻANIA NA GRUNCIE CYWILNOPRAWNEJ REGULACJI WYZYSKU
}

\author{
THE INEXPERIENCE, INEFFICIENCY OR FORCED SITUATION \\ OF A PARTNER IN A PARTNERSHIP
}

\begin{abstract}
Streszczenie: W pracy przeprowadzono rozważania nad wpływem niedoświadczenia, niedołęstwa lub przymusowego położenia wspólnika spółki cywilnej na zawarcie umowy spółki oraz jej funkcjonowanie w obrocie gospodarczym. W tym celu $\mathrm{m}$. in. przeanalizowano wpływ sytuacji, w jakiej znajduje się wspólnik w przypadku reprezentacji jednoosobowej, łącznej oraz umownej. Dokonano założenia, że wyzysk jest wadą oświadczenia woli, co implikuje, że omawiane stany mogą być łączone jedynie z osobami fizycznymi. Stwierdzono, że spółka cywilna, jako uczestnik obrotu gospodarczego, może być postrzegana zarówno jako wyzyskany, jak i wyzyskujący.
\end{abstract}

Słowa kluczowe: wyzysk, spółka cywilna, wada oświadczenia woli

Received: 07.2018

\begin{abstract}
The article involved consideration of the inexperience, inefficiency or forced situation of a partner in a partnership in case of entering into a partnership deed and partnership operation in the course of business. Among others, for this purpose the influence of the situation in which a partner is present in the case of one-person, joint and contractual representation was analyzed. It has been assumed that exploitation is a defect of the declaration of intent, which implies that the discussed states can only be combined with natural persons. It was found that a partnership, as a participant in business transactions, can be perceived as both exploited and exploiting party.
\end{abstract}

Key words: exploitation, partnership, defect of a declaration of intent.

Accepted: 09.2018

\footnotetext{
* Dr, Katedra Prawa Cywilnego II i Prawa Gospodarczego, Wydział Prawa i Administracji Uniwersytet Warmińsko-Mazurski
} 


\section{Wprowadzenie}

Wyzysk jest szczególną, a także, jak pokazuje praktyka, postrzeganą w sposób precyzyjny instytucją prawa cywilnego. Z kolei spółka cywilna jest specyficznym „podmiotem” [Pietrzykowski 2011, 828-829]. Charakter prawny spółki cywilnej nie jest jednolicie ujmowany w doktrynie, chociaż obecnie postrzegany jest głównie jako twór, który nie jest wyposażony przez odrębny przepis w podmiotowość prawną (nie jest zatem jednostką, o której mowa w art. $33^{1}$ k.c.), a przy tym nie mieści się w kategoriach czysto zobowiązaniowych [Jezioro 2008, 1354]. Miejsce regulacji (kodeks cywilny) skłania do stwierdzenia, że jest to umowa obligacyjna. Specyfika spółki cywilnej - na skutek zawarcia umowy spółki powstaje twór odrębny od wspólników - powoduje jednak, że wykracza ona poza wyłącznie zobowiązaniowy charakter.

Wydaje się interesujące poddanie pod rozwagę, czy sytuacja, w jakiej znajduje się wspólnik spółki cywilnej, tym bardziej, że ustawodawca nie wprowadza ograniczeń co do podmiotów prawa cywilnego, które mogą być wspólnikiem w spółce cywilnej, może mieć wpływ na zawarcie umowy spółki oraz jej funkcjonowanie w obrocie gospodarczym. Konkretnie chodzi o stan niedoświadczenia, niedołęstwa lub przymusowego położenia wspólnika, który stanowi jedną z przesłanek zastosowania art. 388 k.c. Dla dokonania analizy przedstawionego problemu niezbędne jest rozróżnienie, czy wspólnikiem jest osobą fizyczną, czy inny podmiot prawa cywilnego.

\section{Regulacja art. 388 k.c.}

W przepisie art. 388 k.c. ustawodawca stanowi: § 1 Jeżeli jedna ze stron, wyzyskując przymusowe położenie, niedołęstwo lub niedoświadczenie drugiej strony, w zamian za swoje świadczenie przyjmuje albo zastrzega dla siebie lub dla osoby trzeciej świadczenie, którego wartość w chwili zawarcia umowy przewyższa w rażącym stopniu wartość jej własnego świadczenia, druga strona może żądać zmniejszenia swojego świadczenia lub zwiększenia należnego jej świadczenia, a w wypadku gdy jedno i drugie byłoby nadmiernie utrudnione, może ona żądać unieważnienia umowy. § 2. Uprawnienia powyższe wygasają z upływem dwóch lat od dnia zawarcia umowy. Z przywołanej regulacji wynika, że istnienie wyzysku determinują przesłanki obiektywne w postaci rażącej dysproporcji świadczeń oraz przesłanek subiektyw- 
nych, tj. (1) wyzyskania (2) przymusowego położenia, niedołęstwa i niedoświadczenia kontrahenta. Wskazane przesłanki muszą być spełnione łącznie, a brak którejkolwiek z nich powoduje, że powołanie się na art. 388 k.c. nie będzie skuteczne.

Rażąca dysproporcja świadczeń jako przesłanka obiektywna, odnoszona jest do wartości świadczeń stron. Na potrzeby art. 388 k.c. należy ją postrzegać w ujęciu obiektywnym, tj. według wartości rynkowej, możliwej do uzyskania w obrocie w ramach popytu i podaży, bez odwoływania się do sentymentalnego lub uczuciowego przywiązania strony do przedmiotu umowy. Na zasadzie autonomii podmiotów i swobody kontraktowania występowanie dysproporcji świadczeń w umowie jest dopuszczalne do momentu, kiedy autonomia zostanie zachowana. Sama dysproporcja, nawet jeśli jest rażąca, nie decyduje o wadliwości czynności prawnej.

Przymusowe położenie występuje, gdy strona znajduje się w takich warunkach materialnych, osobistych lub rodzinnych, które zmuszają ją do zawarcia umowy nawet bez ekwiwalentności świadczeń (za wszelką cenę) oraz nie pozwalają na prowadzenie swobodnych negocjacji [wyrok SN z dnia 27 września 2005 r., V CK 191/05, LEX nr 407057]. Niedoświadczenie to brak ogólnego doświadczenia życiowego bądź brak doświadczenia w określonego rodzaju przedsięwzięciach [wyrok SA w Warszawie z dnia 3 lipca 2009 r., VI ACa 31/09, LEX nr 1120246]. Niedołęstwo definiowane jest jako brak umiejętności sprawnego działania i właściwego prowadzenia swoich spraw, bezradność wobec codziennych problemów i konieczność poszukiwania pomocy u innych, osłabienie czynności psychofizycznych - które wynikają ze stanu zdrowia fizycznego, psychicznego czy wieku. Ponadto niedołęstwo oznacza nieumiejętność podejmowania samodzielnych decyzji, uzależnienie od otoczenia, szczególną podatność na nacisk innych osób, zwłaszcza takich, z którymi łączy wyzyskanego jakiś stosunek zaufania czy zależności, które to cechy miały wpływ na zawarcie umowy [wyrok SA w Warszawie z dnia 14 marca 2014 r., VI ACa 1184/13, LEX nr 1515319]. Należy podkreślić, że przesłanki subiektywne są postrzegane w sposób ścisły.

Samo zawarcie umowy o nieekwiwalentnych świadczeniach przy braku wiedzy i świadomości o znajdowaniu się przez kontrahenta w szczególnym położeniu nie uzasadnia stosowania regulacji art. 388 k.c. i następstw z niego 
wynikających. W przepisie ustawodawca wskazuje, że przesłanką wyzysku jest także wykorzystanie (wyzyskanie) przymusowego położenia, niedołęstwa lub niedoświadczenia drugiej strony stosunku prawnego.

\section{Wyzysk jako wada oświadczenia woli}

Celem kontynuowania rozważań niezbędne jest zajęcie stanowiska co do charakteru prawnego wyzysku. W literaturze przedmiotu oraz judykaturze przedstawiane są w tym zakresie dwa główne stanowiska. Pierwsze traktuje wyzysk jako niedozwoloną treść czynności prawnej [Ohanowicz 1970, 87; Justyński 2004, 98], co argumentuje się m.in. umiejscowieniem art. 388 k.c. poza regulacjami części ogólnej k.c. (systematyka k.c.) [Buczkowski, Wojtaszek 1999, 41].

Drugie, zasługujące w mojej ocenie na aprobatę [Lewandowski 2018, 165], upatruje w wyzysku wady oświadczenia woli [LewaszkiewiczPetrykowska 1973, 180 i nast.; wyrok SA w Poznaniu z dnia 23 listopada 1995 r., I ACr 483/95, LEX nr 24813; wyrok SA w Katowicach z dnia 22 października 1993 r., I ACr 517/93, LEX nr 1649184]. Za tym stanowiskiem przemawia zaakcentowana przez ustawodawcę w przepisie art. 388 k.c. sytuacja strony wyzyskanej oraz nasuwająca się analogia do innych wad oświadczenia woli (np. groźby, podstępu), w których ustawodawca wprost wskazuje na niewłaściwą postawę drugiej strony stosunku wywołującą wadliwość oświadczenia woli. Można stwierdzić, że w przypadku zaistnienia przesłanek wyzysku oświadczenie woli strony umowy jest nieprawidłowe, gdyż nie jest w pełni swobodne, co doprowadza do zachwiania równorzędności wartości świadczeń. Trzeba nadmienić, że twierdzenie, iż wyzysk jest wadą oświadczenia woli nie stoi w sprzeczności z normatywną koncepcją wad oświadczenia woli (tzn. wadami oświadczenia woli są wyłącznie stany, które za wady oświadczenia woli są uznawane $w$ tekście normatywnym). Katalog wad oświadczenia woli wskazany w k.c. (art. 82-88 k.c.) nie jest bowiem zbiorem o enumeratywnym charakterze, o czym świadczą m.in. regulacje art. 945 k.c. oraz art. $15^{1}$ k.r.o.

W związku z powyższym w podjętych rozważaniach wyzysk będzie ujmowany w kategorii wady oświadczenia woli. Przyjęte rozstrzygnięcie ma znaczenie dla analizy wyzysku w przypadku spółki cywilnej, bowiem wady 
oświadczenia woli, z uwagi na występujący w nich komponent psychiczny, mogą być łączone jedynie z osobami fizycznymi, które zdolne są do znajdywania się w tego rodzaju stanach [por. Radwański 2008, 382].

\section{Osoba fizyczna jako podmiot znajdujący się jednej z sytuacji, o których mowa w art. 388 k.c.}

Każdy wspólnik spółki cywilnej, czyli w zasadzie dowolny podmiot prawa cywilnego, może uczestniczyć w czynnościach decyzyjnych i reprezentacyjnych spółki. Tymczasem, przesłanka subiektywna, tj. stan niedoświadczenia, niedołęstwa czy przymusowego położenia jest immanentnie związany wyłącznie z osobą fizyczną. Trzeba zatem podkreślić, że tylko osoba fizyczna, obiektywnie rzecz ujmując, może znajdować się w jednej z sytuacji, o których mowa w art. 388 k.c., niezależnie od roli (funkcji), w której występuje.

W przypadku, gdy wspólnikiem jest osoba fizyczna, niezależnie od tego, czy jest przedsiębiorcą (jeżeli wykonuje działalność gospodarczą), czy takiego statusu nie posiada, sytuacja, w jakiej się znajduje, tj. niedoświadczenie, niedołęstwo lub przymusowe położenie może na podstawie art. 388 k.c. prowadzić do wadliwości złożonego przez wspólnika oświadczenia woli. Z kolei jeśli wspólnikiem spółki cywilnej jest inny niż osoba fizyczna podmiot prawa cywilnego, to analizując wadliwość oświadczenia woli, trzeba odwołać się do teorii organów. Członkiem organu osoby prawnej jest osoba fizyczna, a uczestnikiem jednostki organizacyjnej, która nie jest wyposażona w osobowość prawną, każdy podmiot prawa cywilnego. Na podstawie art. 38 k.c. oraz art. $33^{1} \S 1$ k.c., analizie pod kątem występowania wyzysku, podlega stan, w którym znajduje się osoba fizyczna.

Trzeba zauważyć, że przepisy prawa nie przewidują rygoru szczególnych kompetencji po stronie członków organu, a jedynie przepis art. 18 k.s.h. wprowadza obowiązek posiadania pełnej zdolności do czynności prawnych. Okoliczność ta sama w sobie nie wyłącza jednak znajdowania się przez osobę fizyczną - członka organu w subiektywnych stanach przewidzianych w art. 388 k.c. Członek organu może być niedoświadczony, niedołężny lub znajdować się w przymusowym położeniu, a ten stan powinien być uwzględniany przy ocenie czynności prawnej. Chociaż znajdowanie się w stanie niedoświadczenia zdaje się stać w sprzeczności ze statusem piastuna członka za- 
rządu, to już pozostawanie przez niego w przymusowym położeniu niekoniecznie. Prawdopodobna wydaje się zarówno sytuacja, w której piastun organu osoby prawnej w związku z pełnioną funkcją znajduje się w przymusowym położeniu (tj. ten wyjątkowy stan przymusowego położenia wiąże się z faktem działania w imieniu spółki, nie zaś z jego życiem prywatnym), jak również sytuacja odwrotna, a mianowicie kiedy relacja osobista piastuna organu osoby prawnej przenosi się na pełnioną funkcję.

Należy sądzić, że udział przy dokonywaniu czynności prawnej przez spółkę cywilną osoby fizycznej (w tym także piastuna organu osoby prawnej) niedoświadczonej, niedołężnej lub znajdującej się w przymusowym położeniu powinien, przy spełnieniu pozostałych przesłanek art. 388 k.c., uzasadniać powołanie się na wyzysk. Poza tym, że wspólnik spółki cywilnej może być stroną wyzyskaną, trzeba wskazać, że zawierając umowę, może także być stroną wyzyskującą.

\section{Wyzysk przy zawiązywaniu spółki cywilnej}

Wspólnikiem w spółce cywilnej można się stać w wyniku zawarcia umowy spółki (art. 860 k.c.) lub przystąpienia do niej (np. zmiany istniejącej umowy), a także w wyniku wejścia spadkobierców w miejsce zmarłego wspólnika, jeżeli umowa spółki tak stanowi (por. art. 872 k.c.) [Pietrzykowski 2011, 832]. Z oczywistych względów wyzysk można rozpatrywać w przypadku zawarcia umowy spółki lub jej zmiany.

Przede wszystkim trzeba wskazać, że zakresem zastosowania art. 388 k.c. objęte są ważne [por. wyrok SA w Poznaniu z dnia 27 września 2012 r., I ACa 645/12, Lex nr 1237414] umowy co najmniej dwustronnie zobowiązujące (przepis dotyczy zastrzegania przez jedną stronę świadczenia w zamian za świadczenie drugiej strony, co determinuje, że nie jest możliwe wyzyskanie drugiej strony, dokonując jednostronnej czynności prawnej) [por. Cisek, Kremis 1979, 61; Machnikowski 2014, 704]. Z punktu widzenia tego ogólnego "warunku” badanego na czas zawierania umowy umowa spółki cywilnej może być wadliwa. Chociaż cechą umowy spółki cywilnej jest szczególna rola przypadająca wspólnikom, tj. organizowanie transferu dóbr lub usług między stronami [Radwański 2008, 188], to z treści art. 860 k.c. wynika, że spółkę cywilną mogą zawiązać co najmniej dwie osoby. 
W doktrynie nie ma jednolitego stanowiska co do tego, czy zakres obowiązywania przepisu art. 388 k.c. jest, czy nie jest zawężony do umów wzajemnych [Justyński 2004, 96, 101; Żuławska 2009, 190]. Podobnie nie ma jedności, czy umowa spółki jest umową wzajemną [Pietrzykowski 2011, 832, Węgrzynowski 2011, 418]. Nie rozstrzygając tych wątpliwości, trzeba jednak zająć stanowisko, czy art. 388 k.c. znajduje zastosowanie do umowy spółki cywilnej.

Językowa wykładnia przepisu art. 388 k.c., a konkretnie zwrot „w zamian za swoje świadczenie", zdaje się przemawiać za ograniczeniem stosowania tej regulacji wyłącznie do umów wzajemnych [Justyński 2004, 100]. Trzeba jednak dostrzec, że ustawodawca, regulując wyzysk, nie odniósł się do umowy wzajemnej wprost (por. art. 487 § 2 k.c.), a także nie zastosował charakterystycznej dla niej terminologii, tj. nie zastrzegł, że świadczenia stron mają stanowić swój odpowiednik [Machnikowski 2014, 704]. Celem rozstrzygnięcia, czy wyzysk stosuje się wyłącznie do umowy wzajemnej warto odnieść się do pojęcia ekwiwalentności świadczeń, którą w literaturze przedmiotu postrzega się subiektywnie, obiektywnie bądź według kryterium funkcjonalnego. W tym miejscu wystarczy przyjąć, że zaakcentowana w art. 388 k.c. powinność świadczenia w zamian za świadczenie drugiej strony sprowadza się do założenia, że strona dlatego zobowiązuje się do określonych zachowań, ponieważ druga strona czyni to samo [Ohanowicz 1970, 82]. W pewnym sensie taka koncepcja wpisuje się w sytuację zawarcia spółki cywilnej.

Umowa spółki cywilnej prowadzi do powstania stosunku o charakterze zobowiązaniowym, w którym świadczeniem jest zachowanie się wspólników zmierzające do osiągnięcia wspólnego celu gospodarczego [Jezioro 2008, 1355]. Współdziałanie wspólników (stron) polega w szczególności na wniesieniu wkładów (art. 860 k.c.), ale wydaje się, że także np. na ustaleniu w umowie stosunku udziału wspólnika w zyskach i stratach (art. 867 k.c.). Można zatem wnioskować, że wspólnik zobowiązując się wnieść określony wkład, uzyskuje zobowiązanie drugiej strony polegające np. na zastrzeżeniu w umowie jego wyłączenia od udziału w stratach. Z tej perspektywy, w mojej ocenie, możliwe jest zastosowanie wyzysku przy zawieraniu umowy spółki cywilnej. Na przykład w prostym układzie, gdy umowę spółki cywilnej zawie- 
rają osoby fizyczne, jedna z nich może wykorzystać szczególną sytuację, w jakiej znajduje się druga (np. niedoświadczenie), zastrzegając $w$ umowie spółki korzystną dla siebie wysokość wkładów i równie korzystny stosunek udziału wspólników w zyskach i stratach.

\section{Wyzysk, a występowanie spółki cywilnej w obrocie gospodarczym}

Przepis art. $865 \S 1$ k.c. stanowi, że każdy wspólnik jest uprawniony i zobowiązany do prowadzenia spraw spółki. Do sposobu prowadzenia spraw przez wspólników przepisy dotyczące spółki cywilnej nie wprowadzają szczególnych reguł, dlatego zastosowanie znajdzie przepis art. $354 \S 1$ k.c. [por. Grzybowski 1976, 820]. Natomiast art. 866 k.c. w kwestiach reprezentacji odsyła do analogicznego stosowania przepisów o prowadzeniu spraw, wskazując jedynie, że reprezentacja jest wyłącznie uprawnieniem, nie zaś obowiązkiem.

\section{Prowadzenie spraw spółki cywilnej}

W tzw. modelu ustawowym, gdy wspólnicy nie postanowią nic innego w umowie spółki w sprawach, które nie przekraczają zakresu zwykłych czynności spółki, prawo prowadzenia spraw spółki przysługuje każdemu wspólnikowi samodzielnie (zasady prowadzenia spraw, czyli zarządzania spółką lub inaczej podejmowania decyzji w spółce). Jeżeli jednak przed zakończeniem sprawy chociażby jeden z pozostałych wspólników sprzeciwi się jej prowadzeniu, potrzebna jest uchwała wspólników. Uchwały wspólników są podejmowane jednogłośnie (jednomyślnie) przez wszystkich wspólników tworzących spółkę [por. Grzybowski 1976, 819]. Bez uprzedniej uchwały wspólników każdy wspólnik może wykonać czynność nagłą, której zaniechanie mogłoby narazić spółkę na niepowetowane straty [Nowacki 2013, 1766-1767].

Wskazuje się, że prowadzenie spraw to w przeważającej mierze czynności faktyczne, a zatem nie znajdą do nich zastosowania reguły wynikające z przepisów odnoszących się do wad oświadczenia woli. Dopiero gdy czynność przybierze postać czynności prawnej, można ją analizować pod kątem wad oświadczenia woli. 


\section{Uchwała}

Pod osąd regulacji art. 388 k.c. uzasadnione wydaje się poddanie przypadków, w których muszą być podejmowane uchwały (czynność przekraczająca zwykły zarząd, zgłoszenie sprzeciwu przy czynności zwykłego zarządu). Uchwała nie jest w literaturze przedmiotu postrzegana w sposób jednolity. Należy uznać, że w sytuacji, gdy wywołuje skutki na zewnątrz stanowi czynność prawną, na którą składają się oświadczenia woli osób ją dokonujących.

Wydaje się, że oddanie głosu (złożenie oświadczenia woli) w warunkach występowania jednego z omawianych stanów powoduje, że nie zachodzi jednomyślność, a zatem uchwała może podlegać wzruszeniu. Warto nadmienić, że czynność prawna obarczona wyzyskiem nie jest bezwzględnie nieważna. Dla jej wzruszenia konieczna jest aktywność podmiotu wyzyskanego (strony umowy spółki cywilnej).

Warto zauważyć, że skoro przyjmuje się dopuszczalność stosowania przepisów o wadach oświadczenia woli do uchylenia się wspólnika spółki kapitałowej od oświadczenia woli złożonego w akcie głosowania nad uchwałą [Antoszek 2009, 128 i nast.], to tym bardziej jest to dopuszczalne w spółce cywilnej. Skoro do spółek prawa handlowego regulacje art. 82-88 k.c. stosuje się przez odesłanie z art. 2 k.s.h., to tym bardziej będą one miały zastosowanie na gruncie jednego aktu prawnego (kodeks cywilny).

\section{Reprezentacja w spółce cywilnej}

Jeżeli umowa spółki lub uchwały wspólników nie stanowią inaczej, każdy wspólnik jest umocowany do reprezentowania spółki w takich granicach, w jakich jest uprawniony do prowadzenia jej spraw (art. 866 k.c.). Wydaje się, że należy rozumieć, iż w zwykłych sprawach spółki (np. umowa o bagatelnej wartości), jak również w sprawach nagłych, wspólnik może reprezentować spółkę samodzielnie, natomiast w sprawach przekraczających ten zakres, występować powinni wszyscy wspólnicy (oświadczenie woli, tj. podpisać umowę, powinni złożyć wszyscy wspólnicy) [por. Nazaruk 2013, 1404; Siwik 2015, 95]. Tożsama zasada występuje w sprawach, co do których wspólnik zgłosił sprzeciw. W praktyce problem stanowi rozgraniczenie pomiędzy sprawami zwykłego zarządu a wykraczającymi poza ten zakres. Zasa- 
dy reprezentacji spółki mogą zostać przez wspólników zmienione, w ten sposób, że zamiast ustawowej jednomyślności wymagane będzie współdziałanie kilku wspólników (reprezentacja łączna) bądź działanie wyłącznie jednego wspólnika (reprezentacja jednoosobowa).

\section{Reprezentacja jednoosobowa}

Jeżeli umowa tak stanowi spółkę cywilną reprezentuje jeden wspólnik. Wskazuje się, że wspólnik spółki cywilnej dokonujący czynności prawnej realizuje ją w imieniu (wszystkich) pozostałych wspólników [Herbert 2008, 357]. Inna koncepcja wskazuje, że stroną dokonującą czynności jest sam wspólnik, nie spółka, ani też nie pozostali wspólnicy [Nowacki 2013, 1768]. Według tego poglądu stroną czynności prawnej jest wyłącznie wspólnik, nie jest on przedstawicielem ustawowym pozostałych wspólników, a jedynie z mocy ustawy skutki prawne rozciągają się na pozostałych wspólników [Nowacki 2013, 1768]. Istotne jest, że dokonanie czynności przez wspólnika wpływa w sposób bezpośredni na sytuację prawną wszystkich pozostałych wspólników, ponieważ dotyczy składników majątkowych objętych wspólnością łączną (nabyte prawo wchodzi do majątku wspólnego, a zaciągnięte zobowiązanie rodzi odpowiedzialność solidarną) [Herbert 2008, 357].

Opowiadając się za poglądem, zgodnie z którym wspólnik spółki cywilnej dokonujący czynności prawnej realizuje ją w imieniu (wszystkich) pozostałych wspólników (jako przedstawiciel pozostałych wspólników), to można stwierdzić, że badaniu pod kątem występowania elementów wolicjonalnych i psychologicznych podlegać będzie położenie wspólnika [Pazdan 2008, 468; por. Wyrok Sądu Najwyższego z dnia 27 września 1976 r., IV CR 368/76, LEX nr 2097]. W przypadku reprezentacji jednoosobowej działanie jednego spośród wspólników traktować należy jako działanie spółki. Jeśli wspólnik jest niedoświadczony, niedołężny lub znajduje się w przymusowym położeniu, a przy tym spełnione są pozostałe przesłanki art. 388 k.c. to można powołać się na wyzysk. Stan wspólników nieuczestniczących w akcie reprezentacji będzie irrelewantny z analizowanego punktu widzenia. 


\section{Reprezentacja łączna}

Wydaje się, że również w przypadku reprezentacji łącznej, przy zaistnieniu stanu niedoświadczenia, niedołęstwa lub przymusowego położenia u jednego ze współdziałających wspólników, można powołać się na wyzysk [Herbert 2008, 359]. Możliwe in casu jest, że jednym spośród dokonujących czynności prawnej (reprezentujących spółkę) wspólników będzie taki, który znajduje się w przymusowym położeniu lub jest niedołężny albo niedoświadczony. Przy modelu ustawowym (wymagana jednomyślność) znajdowanie się przez któregoś spośród wspólników w położeniu uzasadniającym przypisanie wyzysku powoduje, że czynność prawna „spółki” - wszystkich wspólników będzie obarczona sankcją wzruszalności. Postawioną tezę można oprzeć na założeniu, że "wyeliminowanie" jednego spośród kilku obligatoryjnych oświadczeń woli sprawia, że nie jest osiągnięta wymagana liczba oświadczeń, co pozostaje w sprzeczności z przepisem art. 866 k.c. Reprezentacja łączna sprawia, że musi być brana pod uwagę sytuacja wszystkich osób dokonujących czynności prawnej. Podnosi się, że w przypadku dokonania czynności prawnej przy zachowaniu reprezentacji łącznej przyjąć należy, że spółka może powołać się na wady oświadczenia woli jednego tylko ze współdziałających, ponosząc jednocześnie negatywne konsekwencje złej wiary albo świadomości pewnych faktów [Herbert 2008, 651-652].

\section{Reguły umowne reprezentacji}

Podobnie, jak w przypadku reprezentacji łącznej, należy opowiedzieć się za dopuszczalnością powołania się na wyzysk, gdy w umowie spółki cywilnej wprowadzono reguły umowne reprezentacji. Teoretycznie, w przypadku złożenia oświadczenia przez większą liczbę podmiotów niż jest wymagana na podstawie reguł umownych, można odwołać się do zasady skutecznej reprezentacji, zgodnie z którą czynność prawna będzie dokonana w sposób prawidłowy, gdy zostanie zgodna z modelem liczby prawidłowo złożonych i skutecznych oświadczeń woli. Wydaje się, że w praktyce taka sytuacja stanowi wyjątek, gdyż nie zdarza się, aby strony wykraczały poza umowną większość reprezentacyjną celem uniknięcia skutków późniejszego wzruszenia takiego oświadczenia woli. 


\section{Podsumowanie}

Przedstawione rozważania pozwalają na stwierdzenie, że art. 388 k.c. może znaleźć zastosowanie do umowy spółki cywilnej (do zawarcia umowy). Wykazano, że spółka cywilna, jako uczestnik obrotu cywilnego, może być postrzegana jako wyzyskany oraz jako wyzyskujący. Istotne jest, że stan niedoświadczenia, niedołęstwa lub znajdowanie się w przymusowym położeniu może dotyczyć wyłącznie osób fizycznych, dlatego dopuszczalność powołania się na wyzysk zachodzi tylko, gdy ten wyjątkowy stan dotyczy osoby fizycznej działającej w imieniu spółki (w związku z czynnością dokonaną w ramach spółki cywilnej).

\section{Bibliografia}

Antoszek P., Cywilnoprawny charakter uchwał wspólników spółek kapitałowych, Wolters Kluwer, Warszawa 2009.

Buczkowski K., Wojtaszek M., Lichwa pieniężna - zagadnienia cywilnoprawne, Przegląd Prawa Handlowego nr 8, 1999.

Cisek A., Kremis J., Z problematyki wyzysku w ujęciu kodeksu cywilnego, Ruch Prawniczy, Ekonomiczny i Socjologiczny z. 3, 1979.

Grzybowski S., [w:] System Prawa Cywilnego, t. III, cz. 2. Prawo zobowiqzań-część szczegółowa, red. S. Grzybowski, Wrocław, Warszawa, Kraków, Gdańsk 1976.

Herbet A., Spółka cywilna. Konstrukcja prawna, C.H. Beck, Warszawa 2008. Jezioro J., [w:] Kodeks cywilny. Komentarz, red. E. Gniewek, C.H.Beck, Warszawa 2008.

Justyński T., Relacja między art. 58 § a art. 388 k.c. w kontekście nadmiernych odsetek umownych, Przegląd Sądowy nr 1, 2004.

Lewandowski P., Charakter prawny wyzysku w prawie cywilnym, maszynopis rozprawy doktorskiej, dostępny w Bibliotece Uniwersyteckiej UWM w Olsztynie.

Lewaszkiewicz-Petrykowska B., Wady oświadczenia woli w polskim prawie cywilnym, Wyd. Prawnicze, Warszawa 1973.

Machnikowski P., [w:] Kodeks cywilny. Komentarz, red. E. Gniewek, C.H.Beck, Warszawa 2014.

Machnikowski P., [w:] System Prawa Prywatnego, t. 5. Prawo zobowiq̨zań - część ogólna, red. E. Łętowska, C.H.Beck, Warszawa 2006.

Nazaruk P., [w:] Kodeks cywilny. Komentarz, (red.) J. Ciszewski, Wolters Kluwer, Warszawa 2013. 
Nowacki A., [w:] Kodeks cywilny. Komentarz t. II. Zobowiqzania, red. K. Osajda, C.H.Beck, Warszawa 2013.

Ohanowicz A., [w:] Zarys prawa zobowiqzań, red. A. Ohanowicz, J. Górski, PWN, Warszawa 1970.

Pazdan M., [w:] System Prawa Prywatnego t. 2, Prawo cywilne - część ogólna, red. Z. Radwański, C.H.Beck, Warszawa 2008.

Pietrzykowski K., [w:] Kodeks cywilny, Tom II. Komentarz do artykułów 450-1088, red. K. Pietrzykowski, C.H.Beck, Warszawa 2011.

Radwański Z., [w:] System Prawa Prywatnego t. 2, Prawo cywilne - część ogólna, red. Z. Radwański, C.H.Beck, Warszawa 2008.

Siwik L., [w:] Spótka cywilna w obrocie gospodarczym, red. M. Podleś, L. Siwik, Wolters Kluwer, Warszawa 2015.

Węgrzynowski Ł., Ekwiwalentność świadczeń w umowie wzajemnej, Wolters Kluwer, Warszawa 2011.

Wyrok SA w Katowicach z dnia 22 października 1993 r., I ACr 517/93, LEX nr 1649184.

Wyrok SA w Poznaniu z dnia 23 listopada 1995 r., I ACr 483/95, LEX nr 24813.

Wyrok SA w Poznaniu z dnia 27 września 2012 r., I ACa 645/12, Lex nr 1237414.

Wyrok SA w Warszawie z dnia 14 marca 2014 r., VI ACa 1184/13, LEX nr 1515319.

Wyrok SA w Warszawie z dnia 3 lipca 2009 r., VI ACa 31/09, LEX nr 1120246.

Wyrok SN z dnia 27 września 1976 r., IV CR 368/76, LEX nr 2097.

Wyrok SN z dnia 27 września 2005 r., V CK 191/05, LEX nr 407057.

Żuławska Cz., [w:] Komentarz do kodeksu cywilnego, Księga trzecia. Zobowiq̨zania t.

1, LexisNexis, Warszawa 2009, s. 190. 